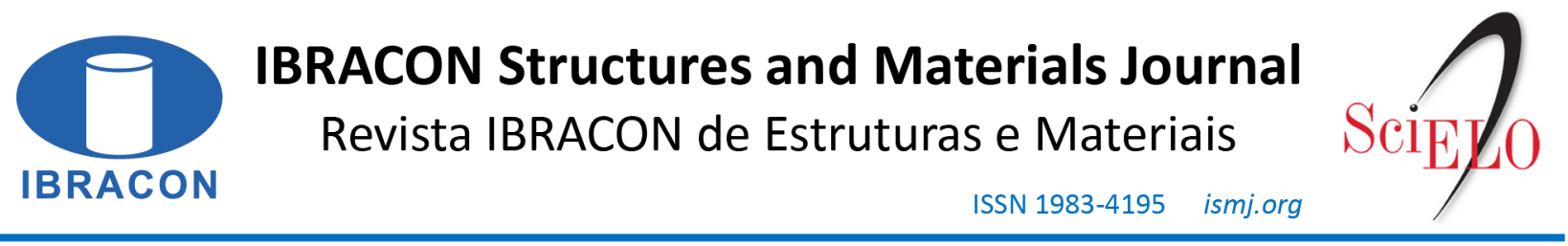

ORIGINAL ARTICLE

\title{
Properties of recycled aggregates from different composition and its influence on concrete strength
}

\section{Propriedades dos agregados reciclados de diferentes composições e sua influência na resistência do concreto}

\author{
Fernanda de Andrade Salgado ${ }^{a}$ \\ Flávio de Andrade Silva ${ }^{\mathrm{a}}$ (D)
}

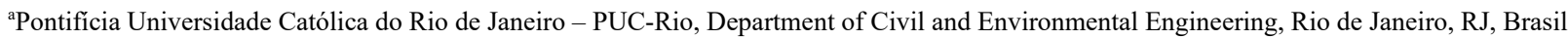

Received 06 August 2020

Accepted 01 March 2021

\begin{abstract}
As a solution to the high depletion of natural resources and huge waste generated by the construction industry, the use of coarse recycled aggregate has become a trend in many countries. The construction and demolition waste is heterogeneous and mostly composed of concrete and masonry debris. The recycling process usually involves not only crushing and screening but also advanced techniques to separate these two fractions. These processes are costly and most frequently ineffective. Although most studies and international standards focused only on recycled concrete aggregate for structural use, it is possible to achieve similar characteristics with mixed recycled aggregates that have a ceramic fraction of up to $20 \%$. This initiative can decrease recycling costs and make it more feasible. Therefore, this work presents an experimental investigation of a Brazilian recycled aggregate, which was separated into three fractions: mixed, concrete, and masonry aggregates. The analyses showed that the mixed recycled aggregate displayed geometric, physical, and mechanical properties similar to the recycled concrete aggregate. In addition, concrete made with $20 \%$ of mixed recycled aggregate presented a reduction of only $0.6 \%$ in maximum compressive strength and $36.8 \%$ in the modulus of elasticity compared with concrete made with the same amount of recycled concrete aggregate.
\end{abstract}

Keywords: sustainability, construction and demolition waste, recycled aggregate.

Resumo: Como solução para o esgotamento dos recursos naturais e o enorme desperdício gerado pela indústria da construção civil, o uso de agregado reciclado graúdo tornou-se uma tendência em muitos países. Os resíduos de construção e demolição são heterogêneos e compostos principalmente por detritos de concreto e cerâmicos. O processo de reciclagem geralmente envolve não apenas trituração e peneiramento, mas também técnicas avançadas para separar essas duas frações. Esses processos são caros e frequentemente ineficazes. Embora a maioria dos estudos e normas internacionais se concentrem apenas em agregados reciclado de concreto para uso estrutural, é possível obter características semelhantes utilizando-se agregados reciclados mistos com uma fração cerâmica de até $20 \%$. Essa iniciativa pode diminuir os custos de reciclagem e tornála mais viável. Portanto, este trabalho apresenta uma investigação experimental de um agregado reciclado brasileiro, que foi separado em três frações: agregado reciclado misto, de concreto e cerâmico. As análises mostraram que o agregado reciclado misto possui propriedades geométricas, físicas e mecânicas semelhantes ao agregado reciclado de concreto. Além disso, o concreto fabricado com $20 \%$ de agregado reciclado misto apresentou uma redução de apenas $0.6 \%$ na resistência máxima à compressão e $36.8 \%$ no módulo de elasticidade em comparação com o concreto fabricado com a mesma quantidade de agregado reciclado de concreto.

Palavras-chave: sustentabilidade, resíduos de construção e demolição, agregado reciclado.

How to cite: F. A. Salgado and F. A. Silva, "Properties of recycled aggregates from different composition and its influence on concrete strength," Rev. IBRACON Estrut. Mater., vol. 14, no. 6, e14605, 2021, https://doi.org/10.1590/S1983-41952021000600005

Corresponding author: Fernanda de Andrade Salgado. E-mail: fernanda.salgado@puc-rio.br

Financial support: None.

Conflict of interest: Nothing to declare. 


\section{INTRODUCTION}

The construction industry is responsible for approximately $23 \%$ of global emission and demands around $4 \times 10^{13}$ $\mathrm{kg}$ per year of raw material since aggregate typically accounts for approximately $70 \%$ of concrete in volume [1], [2]. Besides that, construction of new buildings and demolition of existing structures generate an excessive amount of Construction and Demolition Waste (CDW).

On a global scale, CDW accounts for $36 \%$ by weight of the total waste produced on Earth [3]. The annual CDW production exceeds $1.5 \times 10^{12} \mathrm{~kg}$ in China [4], $5.3 \times 10^{11} \mathrm{~kg}$ in the USA [5], $8.5 \times 10^{11} \mathrm{~kg}$ in European Union [6], and $1.06 \times 10^{11} \mathrm{~kg}$ in Brazil [7]. Thus, improper CDW disposal is a huge problem faced by many countries. Irregular disposal in open dumps has great potential for environmental contamination, causes flooding and landscape damages, and is also harmful to human health as it enables disease proliferation.

Therefore, the use of recycled aggregate from CDW recycling as a replacement for natural coarse aggregate in concrete can promote not only a decrease in the number of irregular waste depositions but can also reduce the consumption of non-renewable natural resources. Thus, many countries, such as USA and European Union members, created waste management plans, looking for waste reduction, the prohibition of uncontrolled disposal, and an increase in the CDW recycling rate [8]. Meanwhile, in Brazil, the recycling plants work, on average, with only $35 \%$ of their capacity, and only $18 \%$ of CDW is recycled [7].

CDW is usually very heterogeneous, and its composition can be affected by several factors, such as the raw materials and the construction and demolition procedures. Frequently, CDW is composed not only of concrete rubble but also crushed clay bricks from partitioning walls and cladding. In Brazil, for example, $70 \%$ of the recycling plants claim to receive predominantly mixed material [7], since wall portioning in most reinforced concrete buildings in Brazil have masonry and CDW collection is disorganized [9].

Because of this heterogeneity, recycled aggregates are usually classified as Recycled Concrete Aggregate (RCA) when it is composed mostly of cement-based fragments and natural rocks, and as Mixed Recycled Aggregate (MRA) when it is composed of a mixture of ceramic debris, bricks, cladding, concrete blocks, and mortar.

International standards usually limit the use of recycled aggregate in concrete depending on the desired concrete strength class and the characteristics of the recycled aggregate. For example, Spanish, British and Portuguese standards limit the use of RCA to $20 \%$ replacement ratio in structural concretes up to C40, while do not mention the use of MRA [10]-[12]. German and Italian standards only allow the use of MRA in non-structural concretes [13], [14]. Meanwhile, the Australian standard allows the use of 100\% MRA in structural concrete C25 if its ceramic content is limited to $30 \%$ [15]. Brazilian standard NBR 15116:2004 [16], however, does not allow the use of either RCA or MRA in structural concrete of any strength class.

The use of RCA as a replacement for natural coarse aggregate has been extensively studied. Most research works have observed that an RCA replacement ratio smaller than 30\% does not induce expressive variations in the mechanical properties and durability aspects of the resulting concrete [17]-[22]. The feasibility of using RCA in structural concrete had also been verified [23]-[26].

Nevertheless, regarding the use of MRA, because of its significantly variable composition, most research papers focused only on road construction and non-structural applications [27]-[32]. However, Yang et al. [33] analyzed the influence of using MRA from a British recycling plant containing different levels of ceramic debris and verified that it was still possible to produce quality concrete with MRA containing up to $20 \%$ of ceramic inclusion. Similar results were obtained with MRA from southwestern Spain and southeast Brazil [34], [35].

In Brazil, MRA are usually employed as road sub-base while RCA are used in non-structural concretes. In the present work, the geometric, physical, and mechanical properties of Brazilian recycled aggregates have been studied. Finally, uniaxial compression tests were assessed on concretes with $20 \%$ recycled aggregate in replacing natural aggregate. The impact of this substitution was evaluated through the analysis of the maximum compressive strength, the modulus of elasticity, and the behaviour of the stress-strain curve.

\subsection{Research significance}

Despite all environmental benefits and the growth potential of the CDW recycling sector, there are still some barriers that hamper the use of recycled aggregates on a larger scale. It is necessary, for example, to ensure that recycling plants will be able to guarantee a consistent supply of high-quality recycled aggregates [36].

Usually, the ordinary recycling process comprehends different stages of crushing, screening, and separation to remove contaminants like reinforcement bars, plastic, and glass, for example. Depending on the maximum size and on the desired composition of the final output, different recycled methods can be applied [37], [38]. 
The removal of contaminants can occur during construction/demolition, optimizing the crushing time in the recycling plant and increasing the quality of the recycled aggregate. However, pre-crushing separation demands more elaborate waste management plans and an organized CDW collection, being more expensive and time-consuming for the contractors. As a second option, CDW can be stockpiled according to major constituents in the recycling plant, and separation can be done only after crushing [39].

In the case of post-crushing separation, when it is necessary to separate the ceramic and the concrete-based fragments, further advanced sorting techniques are used, such as gravity concentration in the presence of water or air [40]. However, in addition to being very expensive, these advanced techniques do not guarantee a complete separation between the ceramic and the concrete-based fractions [41].

Therefore, a better comprehension of MRA properties and its impact on concrete would increase market demand for this material as this initiative can decrease recycling costs and make the recycling process more feasible. Thus, the CDW recycling rate would increase, generating not only numerous environmental benefits but also improving the recycling sector economically.

This paper presents the experimental assessment of a Brazilian recycled aggregate and analyses its influence on the concrete mechanical properties. This study adds to the field important parameters regarding locally available recycled aggregates, being an important step to legitimate its application by the construction sector.

\subsection{Problem definition}

For this work, mixed recycled aggregates (MRA) from a recycling plant located in Brazil was considered. Through manual separation, three samples were produced: (1) mixed recycled aggregates - MRA, (2) recycled concrete aggregates - RCA and (3) recycled masonry aggregates - RMA. The geometric, physical, and mechanical properties of these three samples were compared with a local natural coarse aggregate. Furthermore, to analyze the impact of using recycled aggregates in concrete, the compressive strength of cylindrical specimens containing $20 \%$ in volume of recycled aggregate was assessed at 28 days. This replacement ratio was adopted based on the minimum established by several international standards and codes [42]. The mechanical performance of these recycled concretes was compared with a reference concrete made with $100 \%$ of natural aggregate.

\section{MATERIALS AND EXPERIMENTAL PROGRAM}

\subsection{Aggregates selection}

The mixed recycled aggregates (MRA) were obtained from Reciclax Recycling Plant, Brazil. A certain amount of this MRA sample was cleaned with running water and then air-dried for five days. After that, it was manually separated, providing two other samples of recycled coarse aggregate: recycled concrete aggregate (RCA), composed only of cement-based fragments, and recycled masonry aggregate (RMA), composed only of ceramic debris, bricks and roof tiles. The non-mineral materials such as wood, plastic, bitumen, foam, glass, plaster and metal, were discarded.

Thus, in this study, four types of coarse aggregate were used: mixed recycled aggregate (MRA), recycled concrete aggregate (RCA), recycled masonry aggregate (RMA) and a natural granitic coarse aggregate (NA), as reference.

\subsection{Recycled aggregate characterization}

\subsubsection{Mixed Recycled Aggregate (MRA) composition}

To verify the MRA composition as received from the recycling plant, the percentage by weight of cementitious material, ceramic material, and contaminants/impurities were calculated using a $15 \mathrm{~kg}$ sample. Also, the fine content $(<4.75 \mathrm{~mm})$ and the pulverulent content $(<0.75 \mu \mathrm{m})$ [43] were measured for $10 \mathrm{~kg}$ samples.

In this study, it is considered that the RCA sample is composed entirely of cement-based fragments and natural rocks, while the RMA sample is composed only by masonry elements such as ceramic debris, bricks and roof tiles.

\subsubsection{Geometric properties}

The grain size distribution curves were obtained according to the Brazilian standard NBR NM 248:2003 [44]. Each $8 \mathrm{~kg}$ sample was sieved for 10 minutes. 
The shape index of each aggregate sample was also analyzed, according to the Brazilian standard NBR 7809:2019 [45]. It is used to indicate how rounded the particles are and it is calculated as a relationship between the average length and the average thickness of each material.

\subsubsection{Physical properties}

The specific gravity, the saturated surface-dry density, the oven-dry density, the water absorption and apparent porosity were measured according to the Brazilian standard NBR NM 53:2009 [46]. At first, the samples were ovendried at $105 \pm 5{ }^{\circ} \mathrm{C}$ for $24 \pm 4 \mathrm{~h}$. After being cooled in air-room for 1 to $3 \mathrm{~h}$, the dry masses were obtained. Then, the samples were immersed in water at room temperature for another period of $24 \pm 4 \mathrm{~h}$. After being saturated, they were placed in a holed container and then submerged to determine their apparent masses in water using a hydrostatic scale. Then, samples were rolled in a large absorbent tissue until all visible water film was removed. Finally, saturated surfacedry mass was obtained. This procedure was repeated six times for each type of aggregate.

The bulk density and the void ratio of each sample were measured according to the Brazilian standard NBR NM 45:2006 [47]. This procedure was also repeated six times for each type of aggregate.

The water absorption curve of recycled aggregates was also determined. First, samples were oven-dried at $105 \pm 5{ }^{\circ} \mathrm{C}$ for $24 \pm 4 \mathrm{~h}$. Then, they were placed in a holed container and submerged in water. Using a hydrostatic scale, the mass gain was measured as described below:

- up to the first 15 minutes, one reading every minute;

- from 15-30 minutes, one reading every 5 minutes;

- from 30-60 minutes, one reading every 10 minutes;

- from 1-2 h, one reading every 15 minutes;

- from $2-8 \mathrm{~h}$, one reading every $1 \mathrm{~h}$;

- one last reading after $24 \mathrm{~h}$.

Finally, the packing density was measured to determine the degree of compaction of each type of aggregate. In the case of identical cubic particles and considering the packing of the grains one by one, the packing density would be the maximum possible $(\phi=1)$. Thus, to measure the packing density, a metal cylinder container was filled with oven-dried aggregates and closed with a metal plunger. A mean compression of $10 \mathrm{kPa}$ was applied on the top. Then, it was submitted to a vibrating table for 2 minutes and, finally, the final height of the aggregate sample was measured. The packing density was calculated using the Equation 1 below [48]. The mean of two results was reported as the packing density of each type of aggregate.

$$
\phi=\frac{m}{A_{e} h_{c} \delta}
$$

where $\mathrm{m}=$ mass of the aggregate sample $(\mathrm{kg}) ; A_{e}=$ area of the cylinder container $\left(\mathrm{m}^{2}\right) ; h_{c}=$ final height of the aggregate sample inside the cylinder $(\mathrm{m})$ and $\delta=$ aggregate specific gravity $\left(\mathrm{kg} / \mathrm{m}^{3}\right)$.

\subsubsection{Mechanical behaviour}

The crushing value (ACV) is used to estimate the resistance of an aggregate to crushing under gradually applied compressive load. According to the British standard BS 812 Part 110 [49], the aggregate samples were oven-dried at $105 \pm 5{ }^{\circ} \mathrm{C}$ for a period of not more than $4 \mathrm{~h}$ and then cooled to room temperature. Then, the samples were sifted on sieves $9.5 \mathrm{~mm}$ and $12.5 \mathrm{~mm}$ to remove the oversize and the undersize fractions. The samples were placed in a metal cylinder container in three layers of approximately the same height, being each layer subjected to 25 strokes. A metal plunger was placed carefully and horizontally over the surface of the aggregate. Also according to the British standard BS 812 Part 110 [49], the apparatus was placed on a testing machine and loaded at uniform rate so that the required force of $400 \mathrm{kN}$ was reached in $10 \mathrm{~min} \pm 30 \mathrm{~s}$ (Figure 1). The aggregate crushing value (ACV) was calculated as a relationship between the mass of the material passing the sieve $2.36 \mathrm{~mm}$ after crushing and the total mass. Thus, as lower the crushing value, the higher is the resistance to crushing under a gradually applied compressive load. 


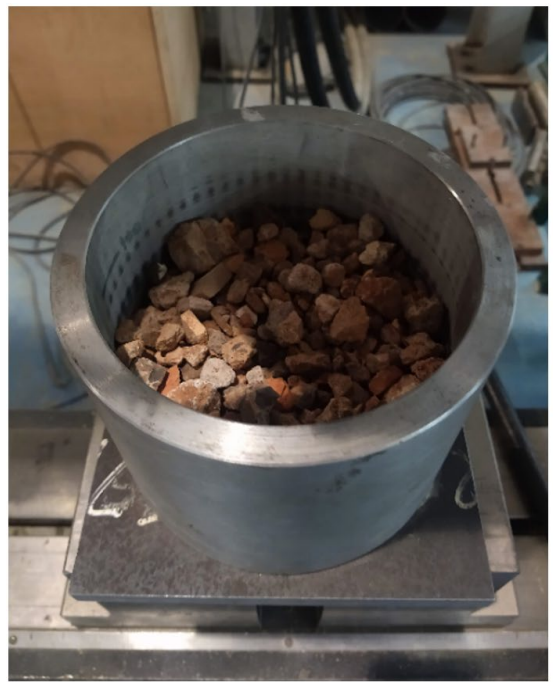

(a)

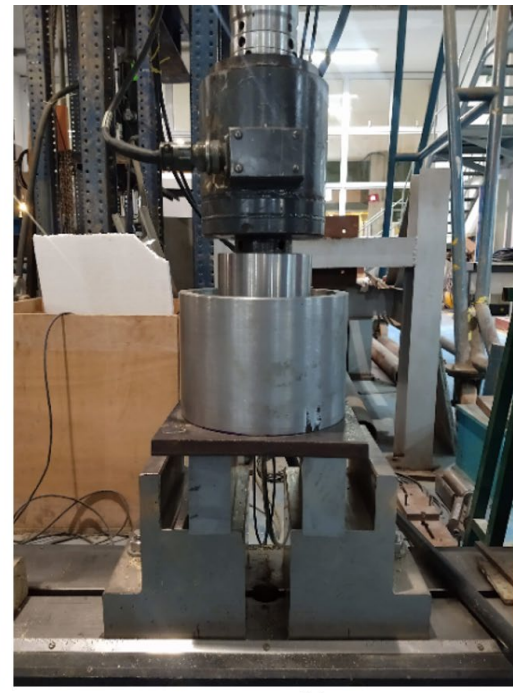

(b)

Figure 1. (a) Aggregate sample inside the metal container and (b) load application

The compressive strength of recycled aggregate concretes was measured at 28 days, using cylindrical specimens $(\phi=100 \mathrm{~mm}$ and $\mathrm{h}=200 \mathrm{~mm})$ [50]. The specimens were prepared with Portland cement CPII F-32, which has a minimum compressive strength of $32 \mathrm{MPa}$ at 28 days [51]. For workability control, a chemical admixture Master Glenium 51 with a solid concentration content of $30 \%$ and specific gravity of $1087 \mathrm{~kg} / \mathrm{m}^{3}$ was used. The superplasticizer content was adjusted from a slump test [52]. Fine aggregate was a quartz natural sand with maximum size of $4.75 \mathrm{~mm}$, specific gravity of $2656 \mathrm{~kg} / \mathrm{m}^{3}$ and water absorption of $4.38 \%$. A reference specimen was fabricated with only natural coarse aggregate (NA); meanwhile, for the recycled aggregate concrete specimens, $20 \%$ in volume of the natural coarse aggregate was replaced for recycled aggregate, as described in Table 1.

Table 1. Concrete samples specifications.

\begin{tabular}{cc}
\hline Sample Name & Percentage of Aggregates in Volume \\
\hline NA-100 & NA $100 \%$ \\
\hline MRA-20 & MRA 20\%, NA $80 \%$ \\
\hline RCA-20 & RCA 20\%, NA $80 \%$ \\
\hline RMA-20 & RMA 20\%, NA $80 \%$ \\
\hline
\end{tabular}

The American Concrete Institute (ACI) mix design method was adopted, with $32 \mathrm{MPa}$ as the desired resistance at 28 days. The w/c ratio was kept constant at 0.50 . Table 2 shows the mix proportion.

Table 2. Mix proportion.

\begin{tabular}{|c|c|}
\hline Material & Mix Proportion $\left(\mathrm{kg} / \mathrm{m}^{3}\right)$ \\
\hline Cement & 360 \\
\hline Fine Aggregate & 727 \\
\hline Coarse Aggregate & 1091 \\
\hline Water & 180 \\
\hline Superplasticizer & 1.08 \\
\hline
\end{tabular}

The mixing process was performed in a 30-liter planetary mixer. The addition of water was done in two parts: $70 \%$ of the total volume was added immediately after mixing the aggregates and the remainder volume (30\%) was added along with the superplasticizer in the end of the mixture. After $24 \mathrm{~h}$, the concrete specimens were demolded and taken 
to a humid chamber for 28 days. The compressive strength tests were performed at a loading speed rate of $0.35 \mathrm{MPa} / \mathrm{s}$ on a Controls machine model MCC8, servo-controlled with a load capacity of $2000 \mathrm{kN}$.

\section{RESULTS AND DISCUSSIONS}

\subsection{Composition, grain size distribution and shape index}

MRA presented $9.26 \pm 0.65 \%$ of fine content and $0.59 \pm 0.31 \%$ of pulverulent material content. These values are under the limit established for the Brazilian standards NBR 15116:2004 [16] and NBR 7211:2009 [53], which limit the fine content to $10 \%$ and the pulverulent content to $1 \%$, respectively.

Table 3 shows that the MRA is composed of less than $90 \%$ of cementitious materials, thus it is indeed classified as mixed recycled aggregates, according to the Brazilian standard NBR 15116:2004 [16]. Contaminants and impurities, such as foam, glass, plaster, plastic, cardboard, shells and even steel nails, represented $0.3 \%$, therefore being within the limit $(<3 \%)$ established by the Brazilian standard [16] for aggregates to be used in concrete. Similar results were obtained by Salles [35].

Table 3. Composition of mixed recycled aggregate (MRA).

\begin{tabular}{cc}
\hline Type of Material & $\%$ \\
\hline Cementitious material & $87.2 \%$ \\
\hline Ceramic material & $12.5 \%$ \\
\hline Contaminants and impurities & $0.3 \%$ \\
\hline
\end{tabular}

All recycled aggregates (MRA, RCA and RMA) presented a continuous (well-graded) grain size distribution curve, which were very similar to each other and also to the natural aggregate (NA) curve (Figure 2). Besides, the maximum size of the four types of aggregates was $19 \mathrm{~mm}$. It can also be observed that the grain size distribution curves of the recycled aggregates were located between zones 4.75/12.5 and 9.5/25, as defined by NBR 7211:2009 [53]. Similar results were presented by Tenório [54].

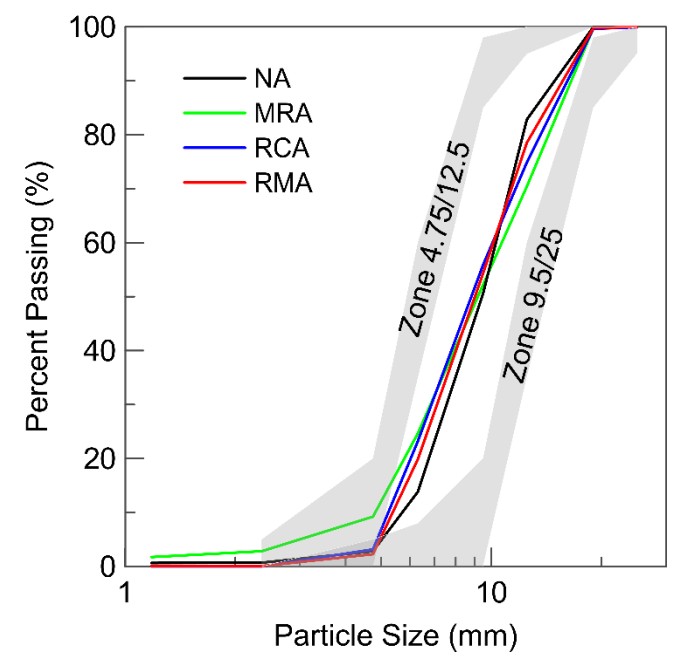

Figure 2. Grain size distribution curves of recycled and natural aggregates.

Moreover, the grain size distribution curve of the MRA used in this study and produced in São Paulo (Brazil) was very similar to those curves obtained for recycled aggregates from several other places in Brazil [35], [55], [56], and also from United Kingdom [33] and India [57] (Figure 3). 


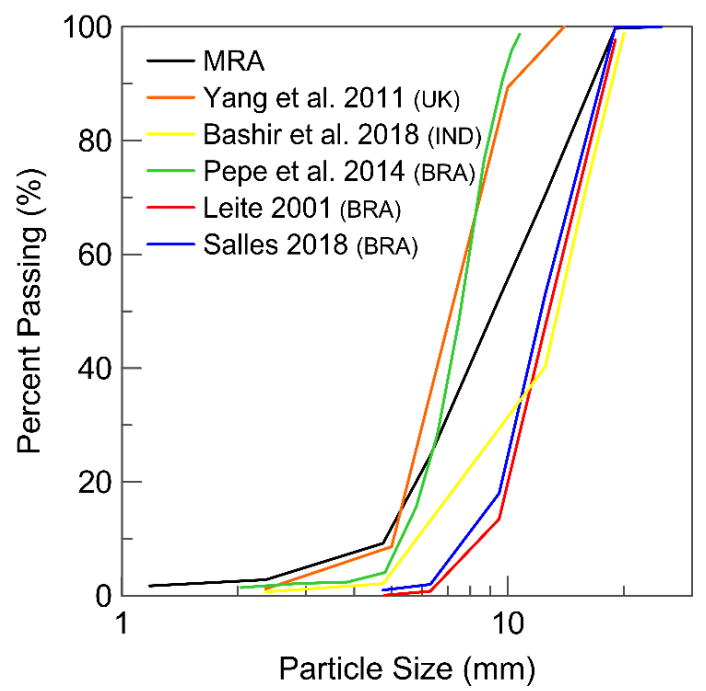

Figure 3. Grain size distribution curves of recycled aggregates from different locations [33], [35], [55]-[57].

Regarding the shape index, the difference between the values obtained for RCA and RMA (Table 4) was consistent with the visual observation of each sample (Figure 4). While RCA was composed of more rounded grains, such as mortar pieces, RMA presented some flatter and elongated grains, such as tiles. It is also possible to visually observe that RCA has a much rougher surface than RMA.

Table 4. Shape index of recycled and natural aggregates.

\begin{tabular}{ccccc}
\hline & NA & MRA & RCA & RMA \\
\hline Average Length $(\mathbf{m m})$ & 19.43 & 20.90 & 19.67 & 20.54 \\
\hline Average Thickness (mm) & 10.39 & 10.02 & 9.99 & 8.74 \\
\hline Shape Index & 1.87 & 2.09 & 1.97 & 2.35 \\
\hline
\end{tabular}

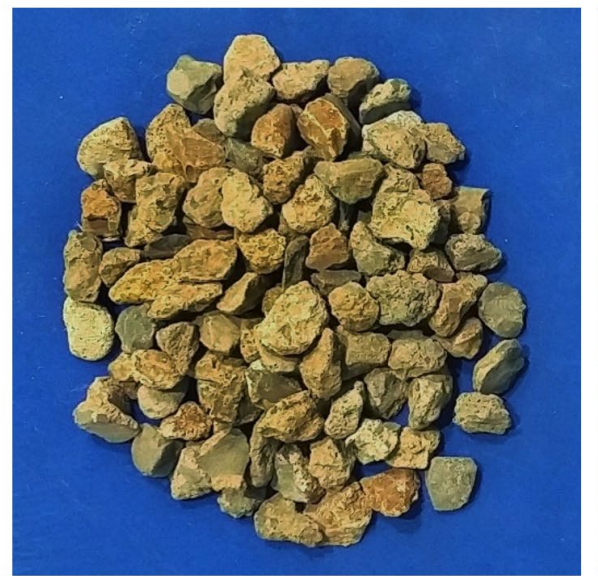

(a)

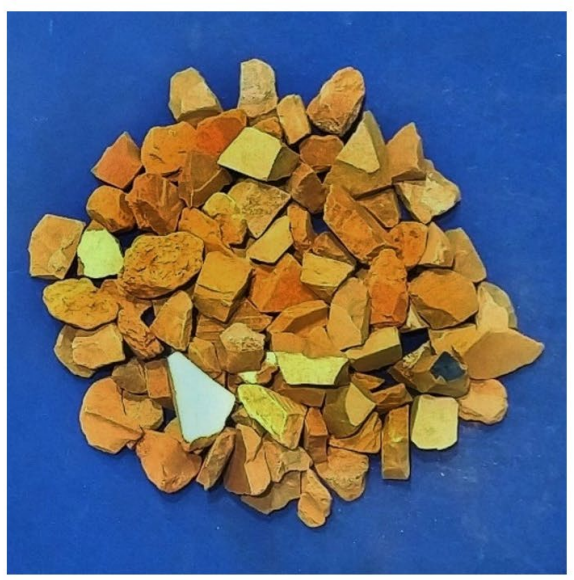

(b)

Figure 4. Picture showing the shapes for: (a) RCA sample and (b) RMA sample.

Meanwhile, Table 4 shows that the shape index of MRA was an intermediate value, which is coherent once MRA was a mixture of the concrete and the masonry fractions (RCA and RMA, respectively). Natural aggregate, however, 
was the most rounded one. Nevertheless, all values were within the limit established by the Brazilian standard NBR 7211:2009 (<3) [53].

\subsection{Physical and mechanical behaviour}

RCA was composed of a natural coarse aggregate with an adhered mortar which is characterized by micro cracks generated during recycling and pores accessible to water. Thus, when compared to the natural aggregate (NA), this adhered mortar was responsible for an increase of $364 \%$ in the apparent porosity and $433 \%$ in the water absorption (Table 5). Equally, RCA presented a reduction of $12 \%$ in oven-dry density in relation to the natural aggregate (NA). The influence of the presence of adherent mortar on the characteristics of RCA was analyzed by Pepe et al. [58]. The authors observed that, after autogenous cleaning, water absorption of RCA reduced almost $50 \%$ and the oven-dry density increased almost 16\%. Limbachiya et al. [59] also investigated RCA with different amount of adhered mortar, observing an increase in water absorption and a reduction in both oven-dry density and SSD density for RCA when the amount of attached cement paste increased.

Meanwhile, as ceramic materials are naturally more porous than natural rocks, RMA presented an apparent porosity $616 \%$ higher, a water absorption $850 \%$ higher and an oven-dried density $25 \%$ lower than the natural aggregate (NA) (Table 5). Similar results were obtained for Cavalline and Weggel [60] when using brick masonry as recycled aggregate. In their study, water absorption increased from $0.34 \%$ for NA to $12.2 \%$ for RMA; while specific gravity reduced from $2840 \mathrm{~kg} / \mathrm{m}^{3}$ for NA to $2190 \mathrm{~kg} / \mathrm{m}^{3}$ for RMA.

Finally, as shown in Table 5, as RCA was responsible for almost $90 \%$ of the composition of the MRA, the results obtained for both were very similar. MRA also exhibited a higher apparent porosity, higher water absorption, and lower density than natural aggregate (NA).

Table 5. Physical properties of recycled and natural aggregates.

\begin{tabular}{|c|c|c|c|c|}
\hline & NA & MRA & RCA & RMA \\
\hline Specific Gravity $\left(\mathrm{kg} / \mathrm{m}^{3}\right)$ & $2653 \pm 3$ & $2626 \pm 12$ & $2631 \pm 9$ & $2497 \pm 8$ \\
\hline SSD Density $\left(\mathrm{kg} / \mathrm{m}^{3}\right)$ & $2601 \pm 6$ & $2350 \pm 6$ & $2396 \pm 10$ & $2164 \pm 9$ \\
\hline Oven-dry Density $\left(\mathrm{kg} / \mathrm{m}^{3}\right)$ & $2570 \pm 10$ & $2181 \pm 14$ & $2253 \pm 13$ & $1942 \pm 12$ \\
\hline Bulk Density $\left(\mathrm{kg} / \mathrm{m}^{3}\right)$ & $1424 \pm 4$ & $1262 \pm 3$ & $1315 \pm 5$ & $1120 \pm 7$ \\
\hline Apparent Porosity (\%) & $3.1 \pm 0.5 \%$ & $16.9 \pm 0.9 \%$ & $14.4 \pm 0.3 \%$ & $22.2 \pm 0.3 \%$ \\
\hline Water Absorption (\%) & $1.2 \pm 0.2 \%$ & $7.8 \pm 0.5 \%$ & $6.4 \pm 0.2 \%$ & $11.4 \pm 0.2 \%$ \\
\hline
\end{tabular}

It was also possible to observe a relationship between the oven-dry density and the apparent porosity, as well as between the water absorption and the apparent porosity (Figure 5). The increase in apparent porosity means an increase in the number of pores, thus, the oven-dry density decreases, and the water absorption increases. 


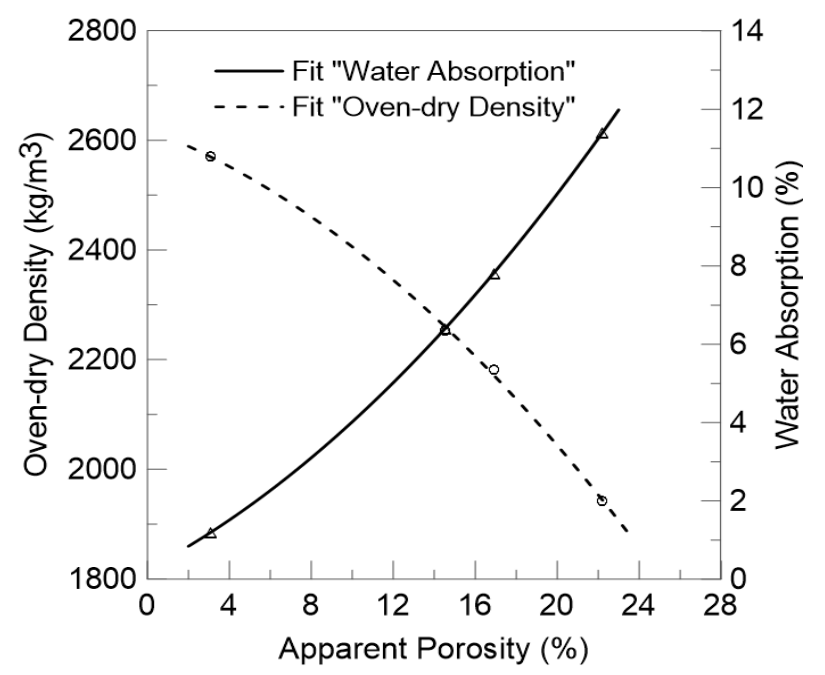

Figure 5. Oven-dry density and Water absorption versus Apparent porosity.

While the apparent porosity measures the total amount of void space accessible from the surface of the aggregate, the void ratio is the number of voids between the aggregates at a certain known volume. Table 6 shows the aggregates void ratio and packing density. It can be observed that the lower the void ratio, the greater was the packing density. However, regardless of the aggregate, the results obtained for void ratio and packing density were very similar to each other. This can be explained by the fact that all aggregates had the same maximum size $(\mathrm{d}=19 \mathrm{~mm})$ and very similar values for shape indexes.

Table 6. Packing density of recycled and natural aggregates.

\begin{tabular}{ccccc}
\hline & NA & MRA & RCA & RMA \\
\hline Void Ratio (\%) & $46.2 \pm 0.2 \%$ & $51.8 \pm 0.1 \%$ & $50.4 \pm 0.2 \%$ & $55.0 \pm 0.3 \%$ \\
\hline Packing Density, $\phi$ & $0.66 \pm 0.01$ & $0.54 \pm 0.0$ & $0.57 \pm 0.01$ & $0.50 \pm 0.01$ \\
\hline
\end{tabular}

Figure 6 shows the $24 \mathrm{~h}$ and the 15 minutes water absorption curves for each aggregate. It can be seen that while the natural aggregate presented a linear behaviour, the recycled aggregates initially showed a higher absorption rate and then reached a saturation plateau. In the first 10 minutes, the natural aggregate (NA) reached $66 \%$ of its total water absorption, while RCA, MRA, and RMA reached 81\%, 82\%, and 90\%, respectively. This behaviour is related to the material's porosity: when the availability of pores is higher, the rate of water absorption in the initial period is also higher. In all cases, the maximum water absorption achieved for each aggregate was similar to the values in Table 5 . Similar results were obtained by Salles [35]: more than $90 \%$ of the final water absorption occurred in the first five minutes of testing for the three types of recycled aggregate analysed (MRA, RCA and RMA). 


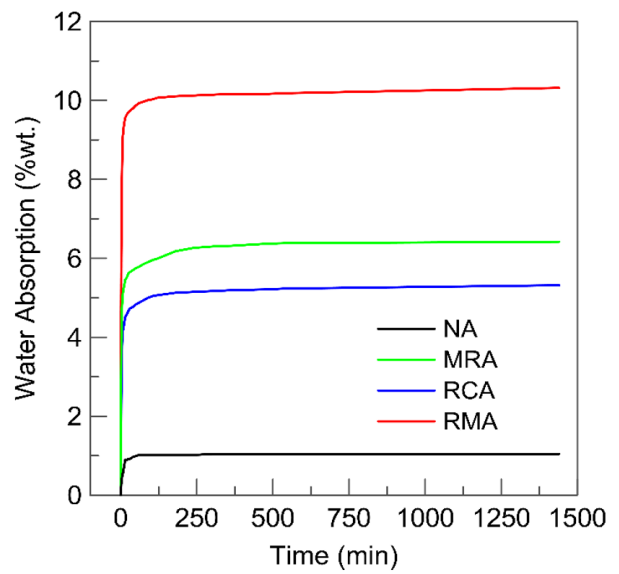

(a)

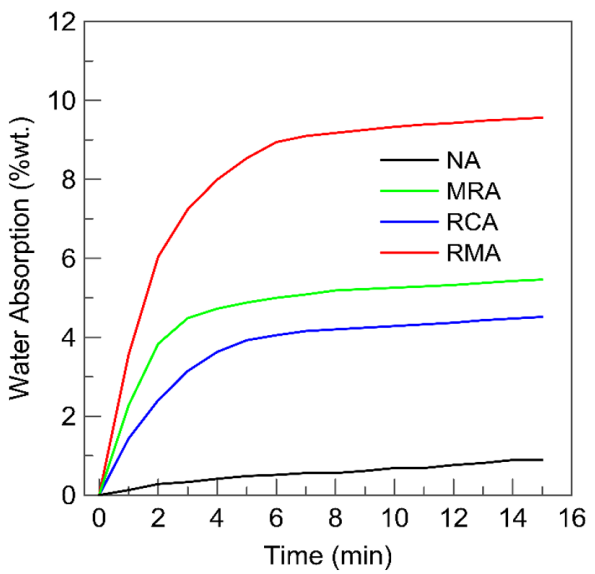

(b)

Figure 6. (a) $24 \mathrm{~h}$ and (b) 15 min water absorption curve of the recycled and the natural aggregates.

Regarding the strength of the aggregate (Table 7), RMA presented a lower resistance to gradually applied compressive load because of its porous and weak composition. Meanwhile, MRA and RCA presented a similar resistance to gradually applied compressive load, which was approximately 15\% higher than RMA and $8 \%$ lower than the natural aggregate (NA). This reduction in strength of MRA and RCA when compared to NA could be explained by the presence of the adhered mortar in the CDW concrete-based fragments: when the adhered mortar increased, their strength decreased. Similar results were obtained by Duan and Poon [61]. The authors analyzed three RCA samples, with different ratios of rock/concrete, by mass, in their composition: $96 \%, 98 \%$, and $99 \%$. They observed that the RCA samples presented similar strength, with a variable reduction from $6 \%$ to $9 \%$ when compared to a natural aggregate sample.

Table 7. Aggregate Crushing Value (ACV) of recycled and natural aggregates.

\begin{tabular}{ccccc}
\hline & NA & MRA & RCA & RMA \\
\hline ACV (\%) & $30.5 \pm 0.2$ & $33.4 \pm 0.4$ & $32.5 \pm 0.5$ & $38.9 \pm 0.5$ \\
\hline
\end{tabular}

Table 8 shows the maximum compressive strength and the modulus of elasticity obtained for each concrete mixture in this study. When compared to the reference concrete (NA-100), concrete made with $20 \%$ of the recycled masonry aggregate (RMA-20) presented a reduction of almost $12 \%$ in the maximum compressive strength and $59 \%$ in the modulus of elasticity. This can be explained by the smoother surface of the RMA (Figure 4), which can lead to a lower adhesion between the aggregate and the matrix, and, consequently, to a lower concrete compressive strength.

Table 8. Maximum compressive strength and modulus of elasticity of concrete made with recycled and natural aggregates.

\begin{tabular}{ccccc}
\hline & NA-100 & MRA-20 & RCA-20 & RMA-20 \\
\hline Maximum compressive strength (MPa) & $31.6 \pm 0.8$ & $28.8 \pm 0.7$ & $29.0 \pm 1.3$ & $27.0 \pm 1.8$ \\
\hline Modulus of elasticity (GPa) & $27.2 \pm 1.8$ & $24.4 \pm 2.5$ & $38.5 \pm 11.1$ & $24.2 \pm 1.5$ \\
\hline
\end{tabular}

Meanwhile, when compared to the reference concrete (NA-100), concrete made with $20 \%$ of recycled concrete aggregate (RCA-20) presented maximum compressive strength $8 \%$ lower and modulus of elasticity $41.5 \%$ higher (Table 8). In the meantime, concrete made with $20 \%$ of mixed recycled aggregate (MRA-20) showed an intermediate behaviour. While its maximum compressive strength was only $0.6 \%$ lower than RCA-20, its modulus of elasticity was $36.8 \%$ lower, being more similar to the modulus of elasticity of the RMA-20.

This reduction in the compressive strength and modulus of elasticity of the RCA-20 and the MRA-20, in comparison with the NA-100, can also be associated to the presence of the adhered mortar in the CDW concrete-based fragments. Some studies have shown that the adhered mortar has a higher tendency to crack, and, in general, the concrete failure happens through the recycled aggregate, within the adhered mortar [20], [62], [63]. 
Bravo et al. [18] related the maximum compressive strength and the modulus of elasticity with the replacement ratio of the recycled aggregate. While studying recycled aggregates from different locations in Portugal, the authors noted a reduction of approximately $5 \%$ and $26 \%$ in the concrete maximum compressive strength for a replacement ratio of $20 \%$ and $100 \%$, respectively; meanwhile, the reduction for the modulus of elasticity was $7.5 \%$ and $37 \%$ for a replacement ratio of $20 \%$ and $100 \%$, respectively.

It is also possible to verify in Table 8 that only the concrete made with $100 \%$ natural aggregate (NA-100) achieved the desired compressive strength (32 MPa). Thus, it can be inferred that the direct replacement of a certain volume of coarse aggregate with recycled aggregate was not effective because it did not take into account the intrinsic characteristics of the recycled aggregates. However, despite these differences in the maximum compressive strength and modulus of elasticity, the stress-strain curves of all concrete mixtures (NA-100, MRA-20, RCA-20, and RMA-20) presented a similar behaviour (Figure 7). It is also important to notice that all concrete samples made with $20 \%$ in volume of recycled aggregate achieved a compressive strength higher than $25 \mathrm{MPa}$. Thus, they could be considered for use in structural elements.

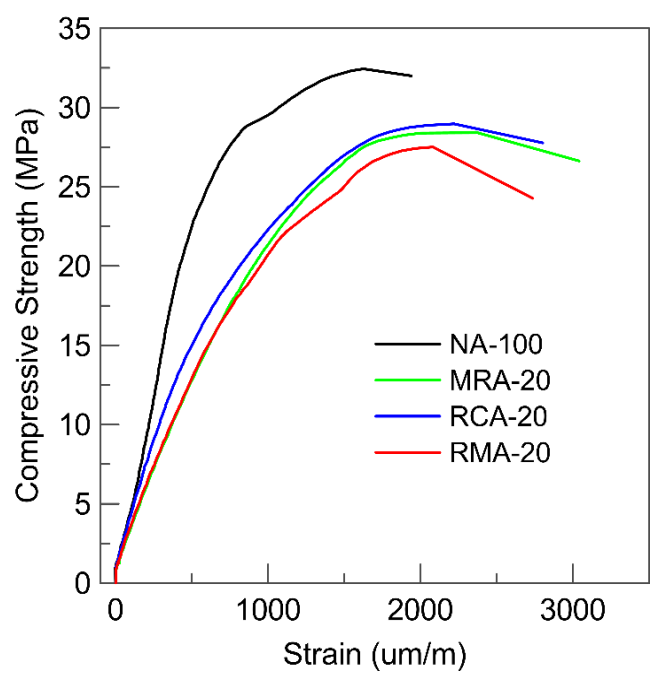

Figure 7. Compressive stress-strain curves.

Many authors investigated the relationship between the modulus of elasticity and the compressive strength of recycled aggregate concretes and different equations have been suggested. Some of these equations are presented in Table 9. It can be observed that there is an expressive variation between all equations not only because of the type of aggregate used in the concrete samples but also because of its physical and mechanical properties.

Table 9. Equations that correlate modulus of elasticity with compressive strength.

\begin{tabular}{ccc}
\hline & Equation & Type of aggregate \\
\hline \multirow{2}{*}{ Ravindrarajah et al. [64] } & $\mathrm{Ec}=5.31 * \mathrm{fc}^{0.5}+5.38$ & Natural aggregate \\
\cline { 2 - 3 } & $\mathrm{Ec}=7.77 * \mathrm{fc}^{0.33}$ & Coarse recycled aggregate \\
\cline { 2 - 3 } & $\mathrm{Ec}=3.48 * \mathrm{fc}^{0.5}-13.1$ & Coarse recycled aggregate \\
\hline Cabral et al. [65] & $\mathrm{Ec}=3.02 * \mathrm{fc}^{0.5}-10.7$ & Coarse and fine recycled aggregate \\
\hline Leite [55] & $\mathrm{Ec}=2.58 * \mathrm{fc}^{0.63}$ & Coarse and fine recycled CDW waste \\
\hline Lovato [66] & $\mathrm{Ec}=4.63 * \mathrm{fc}^{0.5}-3.48 * \mathrm{fc}^{0.5}-13.39$ & Coarse and fine recycled CDW waste \\
\hline Ravindrarajah and Tam [67] & $\mathrm{Ec}=4.63 * \mathrm{fc}^{0.5}$ & Coarse and fine recycled CDW waste \\
\hline
\end{tabular}

Figure 8 shows the equations that correlate the modulus of elasticity with the compressive strength of all concrete mixtures analyzed in this study (NA-100, MRA-20, RCA-20, and RMA-20). It is possible to observe higher 
deformability of concretes made mainly with MRA and RMA. This can be explained by the presence of ceramic materials in the composition of these two types of recycled aggregates.

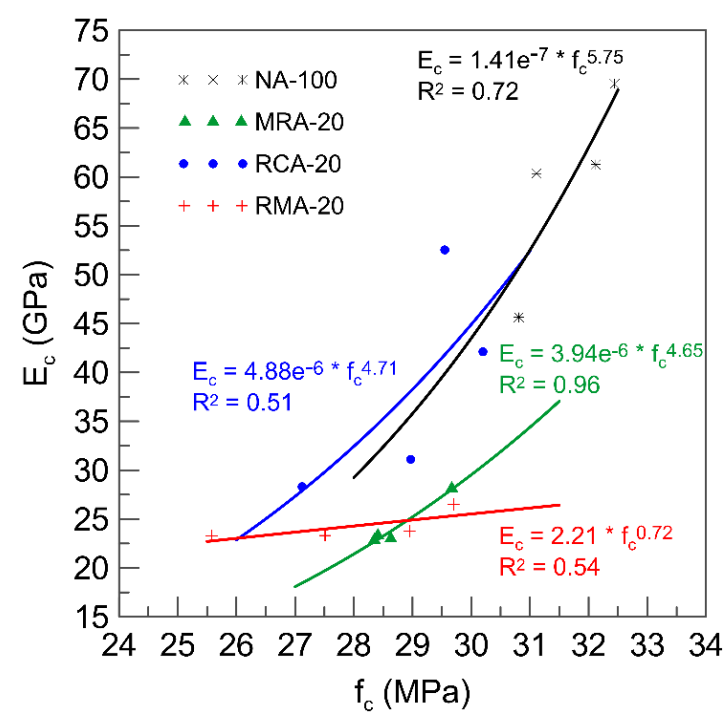

Figure 8. Correlation between modulus of elasticity and compressive strength.

It was also possible to observe a relationship between the apparent porosity and the maximum compressive strength, as well as between the aggregate crushing value and the maximum compressive strength (Figure 9). When the number of pores in the aggregate increases, the maximum compressive strength decrease. Furthermore, as higher is the aggregate crushing value, which means a lower strength of the aggregate, the lower is the concrete maximum compressive strength. Similar results were obtained in other studies. Gómez-Soberón [68] noted that an increase of approximately $4 \%$ in the aggregates total porosity caused a reduction of almost $21 \%$ in the concrete compressive strength. Meanwhile, Duan and Poon [61] observed that an increase of approximately $9 \%$ in the aggregate crushing value, caused a decrease of almost $20 \%$ in the concrete compressive strength.

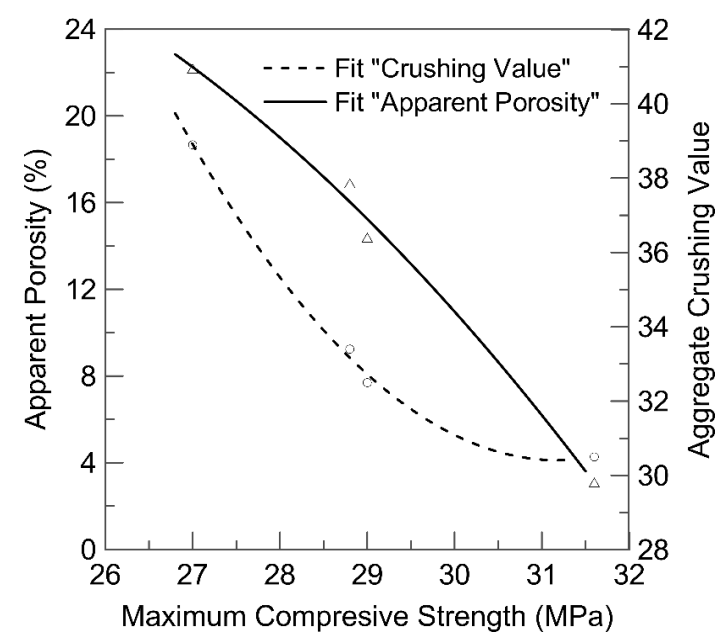

Figure 9. Apparent porosity and Aggregate crushing value versus Maximum compressive strength.

\section{CONCLUSIONS}

Based on the experimental results obtained in the present work, the following conclusions can be drawn: 
- A reduction in the void ratio means a reduction in the number of voids between the aggregates at a certain known volume, thus generating an increase in the packing density. As all aggregates, including the natural one, presented comparable values for shape index and the same maximum size, they all had very similar values of void ratio and, consequently, for packing density;

- Because of its higher porosity, the recycled aggregates were less dense, less resistant and absorbed more water than the natural aggregate. All recycled aggregates absorbed almost $90 \%$ of the total water after approximately 12 minutes. This must be taken into account when mixing the concrete, since the water absorption by the aggregates can reduce the amount of water available for the cement hydration reaction;

- Only the concrete made with 100\% natural aggregate achieved the desired maximum compressive strength, demonstrating that the strategy of applying a direct replacement ratio for the recycled aggregate must be rethought as a mix design method, since it does not take into account the inherent characteristics of these aggregates;

- Despite this reduction, it was possible to obtain a compressive strength greater than $25 \mathrm{MPa}$ for all samples made with $20 \%$ in volume of recycled aggregates. This could be is a satisfactory result for the use of this material in structural elements. Furthermore, similarly to several international standards, this percentage of substitution could be seen as a starting point for a possible revision of the Brazilian standard NBR 15116:2004, which regulates the use of recycled aggregates in concrete;

- In general, the properties obtained for the mixed recycled aggregate (MRA) were very close to those obtained for the recycled aggregate composed only by the concrete fraction (RCA). There was also little variation in the mechanical strength of concretes manufactured with $20 \%$ in volume of MRA and RCA in substitution of the natural aggregate. This demonstrates that the MRA with a small ceramic fraction $(<15 \%)$ can be directly used by the construction industry, without the need to separate the masonry and concrete fractions. Thus, the recycling process becomes cheaper and more attractive for the use of the recycled aggregate on a large scale.

\section{ACKNOWLEDGEMENTS}

This study was financed in part by the Coordenação de Aperfeiçoamento de Pessoal de Nível Superior - Brasil (CAPES) - Finance Code 001. The authors would also like to acknowledge the support from CNPq, FINEP, FAPERJ and Reciclax Recycling Plant.

\section{REFERENCES}

[1] S. Kosmatka, B. Kerkhoff, and W. Paranese, Design and Control of Concrete Mixtures, 14th ed. Portland Cement Association, 2008.

[2] L. Huang, G. Krigsvoll, F. Johansen, Y. Liu, and X. Zhang, "Carbon emission of global construction sector," Renew. Sustain. Energy Rev., vol. 81, pp. 1906-1916, 2018, http://dx.doi.org/10.1016/j.rser.2017.06.001.

[3] International Solid Waste Association, ISWA REPORT ISWA at a Glance, Viena, AUT, 2015.

[4] B. Huang, X. Wang, H. Kua, Y. Geng, R. Bleischwitz, and J. Ren, "Construction and demolition waste management in China through the 3R principle," Resour. Conserv. Recycling, vol. 129, pp. 36-44, 2018., http://dx.doi.org/10.1016/j.resconrec.2017.09.029.

[5] U.S. Environmental Protection Agency. Advancing Sustainable Materials Management: 2014 Fact Sheet. Washington: USEPA, 2016. Accessed: Apr. 4, 2018. [Online]. Available: https://www.epa.gov/sites/production/files/2016-

11/documents/2014_smmfactsheet_508.pdf

[6] European Environmental Agency. ETC/SCP, EU as a Recycling Society - Present recycling levels of Municipal Waste and Construction \& Demolition Waste in the EU. Copenhagen: DNK, 2009, pp. 73.

[7] Associação Brasileira para Recicilagem de Resíduos da Construção Civil e Demolição, Relatório Pesquisa Setorial $2017 / 2018$. ABRECON, 2018, pp. 75.

[8] U.S. Environmental Protection Agency. Industrial and Construction and Demolition (C\&D) Landfills. Washington: USEPA, 2018. Accessed: Apr. 4, 2018. [Online]. Available: https://www.epa.gov/landfills/industrial-and-construction-and-demolition-cd-landfills

[9] E. Vázquez, Ed. Progress of Recycling in the Built Environment - Final Report of the RILEM Technical Committee 217-PRE. Netherlands: Springer, 2013.

[10] British Standards Institution, Concrete - Complementary British Standard to BS EN 206 - Part 2: Specification for Constituent Materials and Concrete, BS 8500-2, 2015, pp. 48.

[11] EHE, EHE-08 - Instrucción de Hormigón Estructural. Ministerio de Fomento S.G.T. Centro de Publicaciones, ESP., 2008, pp. 258266.

[12] Lisboa. Ministério das Obras Públicas, Transportes e Comunicações. Laboratório Nacional de Engenharia Civil. Guia para Utilização de Agregados Reciclados Grossos em Betões de Ligantes Hidráulicos, E 471-2009. Lisboa: LNEC, 2009 , pp. 8. 
[13] Deutches Institut fûr Normung e.V., Aggregates for Concrete, DIN EN 12620, 2003, pp. 47.

[14] Ministero delle Infrastrutture, M_INF-TFE, NTC 2008 -Italian Building Code. D.M. 14/01/2008. ITA, 2008, p. 448.

[15] Commonwealth Scientific and Industrial Research Organisation, Guide to the Use of Recycled Concrete and Masonry Materials, CSIRO HB 155, 2002, pp. 80.

[16] Associação Brasileira de Normas Técnicas, Agregados Reciclados de Resíduos Sólidos da Construção Civil - Utilização em Pavimentação e Preparo de Concreto sem Função Estrutural - Requisitos, NBR 15116, 2004.

[17] G. Bai, C. Zhu, C. Liu, and B. Liu, "An evaluation of the recycled aggregate characteristics and the recycled aggregate concrete mechanical properties," Constr. Build. Mater., vol. 240, pp. 117978, 2020, http://dx.doi.org/10.1016/j.conbuildmat.2019.117978.

[18] M. Bravo, J. De Brito, J. Pontes, and L. Evangelista, "Mechanical performance of concrete made with aggregates from construction and demolition waste recycling plants," J. Clean. Prod., vol. 99, pp. 59-74, 2015, http://dx.doi.org/10.1016/j.jclepro.2015.03.012.

[19] V. Corinaldesi, "Mechanical and elastic behaviour of concretes made of recycled-concrete coarse aggregates," Constr. Build. Mater., vol. 24, no. 9, pp. 1616-1620, 2010, http://dx.doi.org/10.1016/j.conbuildmat.2010.02.031.

[20] M. Etxeberria, E. Vázquez, A. Marí, and M. Barra, "Influence of amount of recycled coarse aggregates and production process on properties of recycled aggregate concrete," Cement Concr. Res., vol. 37, no. 5, pp. 735-742, 2007, http://dx.doi.org/10.1016/j.cemconres.2007.02.002.

[21] V. W. Y. Tam, D. Kotrayothar, and J. Xiao, "Long-term deformation behaviour of recycled aggregate concrete," Constr. Build. Mater., vol. 100, pp. 262-272, 2015, http://dx.doi.org/10.1016/j.conbuildmat.2015.10.013.

[22] C. Thomas, J. Setién, J. A. Polanco, P. Alaejos, and M. Sánchez De Juan, "Durability of recycled aggregate concrete," Constr. Build. Mater., vol. 40, pp. 1054-1065, 2013, http://dx.doi.org/10.1016/j.conbuildmat.2012.11.106.

[23] M. Etxeberria, A. R. Marí, and E. Vázquez, "Recycled aggregate concrete as structural material," Mater. Struct. Constr., vol. 40, no. 5, pp. 529-541, 2007., http://dx.doi.org/10.1617/s11527-006-9161-5.

[24] X. Li, "Recycling and reuse of waste concrete in China. Part II. Structural behaviour of recycled aggregate concrete and engineering applications," Resour. Conserv. Recycling, vol. 53, no. 3, pp. 107-112, 2009, http://dx.doi.org/10.1016/j.resconrec.2008.11.005.

[25] N. Mohamad, H. Khalifa, A. A. Abdul Samad, P. Mendis, and W. I. Goh, "Structural performance of recycled aggregate in CSP slab subjected to flexure load," Constr. Build. Mater., vol. 115, pp. 669-680, 2016, http://dx.doi.org/10.1016/j.conbuildmat.2016.04.086.

[26] H. Zhang and Y. Zhao, "Performance of recycled aggregate concrete in a real project," Adv. Struct. Eng., vol. 17, no. 6, pp. 895-906, 2014, http://dx.doi.org/10.1260/1369-4332.17.6.895.

[27] J. R. Jiménez, J. Ayuso, A. P. Galvín, M. López, and F. Agrela, "Use of mixed recycled aggregates with a low embodied energy from non-selected CDW in unpaved rural roads," Constr. Build. Mater., vol. 34, pp. 34-43, 2012, http://dx.doi.org/10.1016/j.conbuildmat.2012.02.042.

[28] F. D. C. Leite, R. D. S. Motta, K. L. Vasconcelos, and L. Bernucci, "Laboratory evaluation of recycled construction and demolition waste for pavements," Constr. Build. Mater., vol. 25, no. 6, pp. 2972-2979, 2011, http://dx.doi.org/10.1016/j.conbuildmat.2010.11.105.

[29] I. Martínez-Lage, F. Martínez-Abella, C. Vázquez-Herrero, and J. L. Pérez-Ordóñez, "Properties of plain concrete made with mixed recycled coarse aggregate," Constr. Build. Mater., vol. 37, pp. 171-176, 2012, http://dx.doi.org/10.1016/j.conbuildmat.2012.07.045.

[30] B. Mas et al., "Concrete with mixed recycled aggregates: Influence of the type of cement," Constr. Build. Mater., vol. 34, pp. 430441, 2012, http://dx.doi.org/10.1016/j.conbuildmat.2012.02.092.

[31] J. Tavira, J. R. Jiménez, J. Ayuso, M. J. Sierra, and E. F. Ledesma, "Functional and structural parameters of a paved road section constructed with mixed recycled aggregates from non-selected construction and demolition waste with excavation soil," Constr. Build. Mater., vol. 164, pp. 57-69, 2018, http://dx.doi.org/10.1016/j.conbuildmat.2017.12.195.

[32] I. Vegas, J. A. Ibañez, A. Lisbona, A. Sáez De Cortazar, and M. Frías, "Pre-normative research on the use of mixed recycled aggregates in unbound road sections," Constr. Build. Mater., vol. 25, no. 5, pp. 2674-2682, 2011, http://dx.doi.org/10.1016/j.conbuildmat.2010.12.018.

[33] J. Yang, Q. Du, and Y. Bao, "Concrete with recycled concrete aggregate and crushed clay bricks," Constr. Build. Mater., vol. 25, no. 4, pp. 1935-1945, 2011, http://dx.doi.org/10.1016/j.conbuildmat.2010.11.063.

[34] B. Cantero, I. F. Sáez del Bosque, A. Matías, and C. Medina, "Statistically significant effects of mixed recycled aggregate on the physical-mechanical properties of structural concretes," Constr. Build. Mater., vol. 185, pp. 93-101, 2018, http://dx.doi.org/10.1016/j.conbuildmat.2018.07.060.

[35] P. V. Salles, “Avaliação mecânica e de durabilidade de concretos fabricados com resíduos de construção e demolição,” M.S. thesis, Cent. Fed. Educ. Tecnol. Minas Gerais, Belo Horizonte, 2018.

[36] Y. Kasai, K. D. Ravindra, A. H. Neil, and C. L. Mukesh, "Barriers to the reuse of construction by-products and the use of recycled aggregate in concrete in Japan," Sustain. Constr. Use Recycl. Concr. Aggreg., 2015. Accessed: Apr. 4, 2018. [Online]. Available: https://www.icevirtuallibrary.com/doi/abs/10.1680/scuorca.27268.0038 
[37] C. Medina, W. Zhu, T. Howind, M. Frías, and M. I. Sánchez de Rojas, "Effect of the constituents (asphalt, clay materials, floating particles and fines) of construction and demolition waste on the properties of recycled concretes," Constr. Build. Mater., vol. 79, pp. 22-33, 2015, http://dx.doi.org/10.1016/j.conbuildmat.2014.12.070.

[38] M. Quattrone, S. C. Angulo, and V. M. John, "Energy and $\mathrm{CO}_{2}$ from high performance recycled aggregate production," Resour. Conserv. Recycling, vol. 90, pp. 21-33, 2014, http://dx.doi.org/10.1016/j.resconrec.2014.06.003.

[39] R. V. Silva, J. Brito, and R. K. Dhir, "Availability and processing of recycled aggregates within the construction and demolition supply chain: a review," J. Clean. Prod., vol. 143, pp. 598-614, 2017, http://dx.doi.org/10.1016/j.jclepro.2016.12.070.

[40] K. Hu, Y. Chen, F. Naz, C. Zeng, and S. Cao, "Separation studies of concrete and brick from construction and demolition waste," Waste Manag., vol. 85, pp. 396-404, 2019, http://dx.doi.org/10.1016/j.wasman.2019.01.007.

[41] I. Vegas, K. Broos, P. Nielsen, O. Lambertz, and A. Lisbona, "Upgrading the quality of mixed recycled aggregates from construction and demolition waste by using near-infrared sorting technology," Constr. Build. Mater., vol. 75, pp. 121-128, 2015, http://dx.doi.org/10.1016/j.conbuildmat.2014.09.109.

[42] V. W. Y. Tam, M. Soomro, and A. C. J. Evangelista, "A review of recycled aggregate in concrete applications (2000-2017)," Constr. Build. Mater., vol. 172, pp. 272-292, 2018, http://dx.doi.org/10.1016/j.conbuildmat.2018.03.240.

[43] Associação Brasileira de Normas Técnicas, Agregados - Determinação do Material Fino que Passa Através da Peneira 75 um, por Lavagem, NBR NM 46, 2003.

[44] Associação Brasileira de Normas Técnicas, Agregados - Determinação da Composição Granulométrica, NBR NM $248,2003$.

[45] Associação Brasileira de Normas Técnicas, Agregado Graúdo - Determinação do Índice de Forma pelo Método do Paquímetro Método de Ensaio, NBR 7809, 2019.

[46] Associação Brasileira de Normas Técnicas, Agregado Graúdo - Determinação da Massa Específica, Massa Especifica Aparente e Absorção de Água, NBR NM 53, 2009.

[47] Associação Brasileira de Normas Técnicas, Agregados - Determinação da Massa Unitária e do Volume de Vazios, NBR NM 45, 2006.

[48] F. de Larrard, Concrete Mixture Proportioning: a Scientific Approach. London, UK: E\&FN Spon, 1999.

[49] British Standards Institution, Part 110 - Aggregate Crushing Value, BS 812, 1990.

[50] Associação Brasileira de Normas Técnicas, Concreto - Ensaio de Compressão de Corpos de Prova Cilíndricos, NBR $5739,2018$.

[51] Associação Brasileira de Normas Técnicas, Cimento Portland - Requisitos, NBR 16697, 2018.

[52] Associação Brasileira de Normas Técnicas, Concreto - Determinação da Consistência pelo Abatimento do Tronco de Cone, NBR NM 67, 1998.

[53] Associação Brasileira de Normas Técnicas, Agregado para Concreto - Especificação, NBR 7211, 2009.

[54] J. J. L. Tenório, “Avaliação de propriedades do concreto produzido com agregados reciclados de resíduos de construção e demolição visando aplicações estruturais,” M.S. thesis, Univ. Fed. Alagoas, 2007.

[55] M. B. Leite, "Avaliação de propriedades mecânicas de concretos produzidos com agregados reciclados de resíduos de construção e demolição,” Ph.D. dissertation, Univ. Fed. Rio Grande do Sul, 2001.

[56] M. Pepe, R. D. Toledo Fo., E. A. B. Koenders, and E. Martinelli, "Alternative processing procedures for recycled aggregates in structural concrete," Constr. Build. Mater., vol. 69, pp. 124-132, 2014, http://dx.doi.org/10.1016/j.conbuildmat.2014.06.084.

[57] A. Bashir, G. Chhavi, A. M. Abubakar, and S. I. Abba, "Comparison of properties of coarse aggregate obtained from recycled concrete with that of conventional coarse aggregates," Eur. J. Adv. Eng. Technol., vol. 5, no. 8, pp. 628-637, 2018., http://dx.doi.org/10.13140/RG.2.2.35863.83361.

[58] M. Pepe, R. D. Toledo Fo., E. A. B. Koenders, and E. Martinelli, "A novel mix design methodology for Recycled Aggregate Concrete," Constr. Build. Mater., vol. 122, pp. 362-372, 2016, http://dx.doi.org/10.1016/j.conbuildmat.2016.06.061.

[59] M. C. Limbachiya, T. Leelawat, and R. K. Dhir, "Use of recycled concrete aggregate in high-strength concrete," Mater. Struct., vol. 33, no. 9, pp. 574-580, 2000, http://dx.doi.org/10.1007/BF02480538.

[60] T. L. Cavalline and D. C. Weggel, "Recycled brick masonry aggregate concrete:Use of brick masonry from construction and demolition waste as recycled aggregate in concrete," Struct. Surv., vol. 31, no. 3, pp. 160-180, 2013, http://dx.doi.org/10.1108/SS-092012-0029.

[61] Z. H. Duan and C. S. Poon, "Properties of recycled aggregate concrete made with recycled aggregates with different amounts of old adhered mortars," Mater. Des., vol. 58, pp. 19-29, 2014, http://dx.doi.org/10.1016/j.matdes.2014.01.044.

[62] G. C. Lee and H. B. Choi, "Study on interfacial transition zone properties of recycled aggregate by micro-hardness test," Constr. Build. Mater., vol. 40, pp. 455-460, 2013, http://dx.doi.org/10.1016/j.conbuildmat.2012.09.114.

[63] Q. Liu, J. Xiao, and Z. Sun, "Experimental study on the failure mechanism of recycled concrete," Cement Concr. Res., vol. 41, no. 10, pp. 1050-1057, 2011, http://dx.doi.org/10.1016/j.cemconres.2011.06.007. 
[64] R. S. Ravindrarajah, M. Stewart, and D. Greco, "Variability of recycled concrete aggregate and its effects on the properties of concrete," in Proc. 2nd Int. Conf. Eng. Mater., California, USA, 2001.

[65] A. E. B. Cabral, V. Schalch, D. C. C. D. Molin, and J. L. D. Ribeiro, "Mechanical properties modeling of recycled aggregate concrete," Constr. Build. Mater., vol. 24, no. 4, pp. 421-430, 2010, http://dx.doi.org/10.1016/j.conbuildmat.2009.10.011.

[66] P. S. Lovato, "Verificação dos parâmetros de controle de agregados reciclados de resíduos de construção e demolição para utilização em concreto," M.S. thesis, Univ. Fed. Rio Grande do Sul, 2007.

[67] R. S. Ravindrarajah and C. Tam, "Properties of concrete made with crushed concrete as coarse aggregate," Mag. Concr. Res., vol. 37, no. 130, pp. 29-38, 1985, http://dx.doi.org/10.1680/macr.1985.37.130.29.

[68] J. M. V. Gómez-Soberón, "Porosity of recycled concrete with substitution of recycled concrete aggregate: an experimental study," Cement Concr. Res., vol. 32, no. 8, pp. 1301-1311, 2002, http://dx.doi.org/10.1016/S0008-8846(02)00795-0.

Author contributions: SALGADO, FA: conceptualization, formal analysis, methodology, writing; SILVA, FA: funding acquisition, supervision.

Editors: Yury Andrés Villagrán Zaccardi, Guilherme Aris Parsekian. 